\title{
Bioherbicidal action of Phoma dimorpha fermented broth on seeds and plants of Senna obtusifolia ${ }^{1}$
}

\author{
José Roberto Chaves Neto ${ }^{2}$, Marcio Antonio Mazutti ${ }^{3}$, \\ Giovani Leone Zabot ${ }^{4}$, Marcus Vinícius Tres ${ }^{4}$
}

\section{ABSTRACT}

The weed Senna obtusifolia causes severe damages to pasture areas in Brazil, due to its high production and seed spread. This study aimed to evaluate the bioherbicidal action of Phoma dimorpha fermented broth in the pre-emergence and post-emergence of $S$. obtusifolia. The experimental design was completely randomized, with two treatments, one with and other without the application of the fermented broth. The bioherbicidal effects were measured in bioassays of pre-emergence (germination percentage), detached leaves (phytotoxicity) and post-emergence (phytotoxicity, plant height and fresh plant mass). The application of the fermented broth provided a pre-emergence bioherbicidal action, inhibiting the seed germination in $100 \%$. In detached leaves, it caused leaf necrosis and death on the ninth day after the application. In the post-emergence, this application caused moderate symptoms, such as leaf spots and reduction in the weed plant size. It was concluded that the $P$. dimorpha fermented broth has a potential herbicidal action and, therefore, represents an alternative in the development of bioproducts for a sustainable weed control in pastures.

KEYWORDS: Senna obtusifolia, biological control, phytotoxicity, weed.

\section{INTRODUCTION}

The increasing weed infestation in growing areas may be responsible for significant reductions in crop yields. Several studies confirm the toxic potential and greater competitive power of weeds over cultivated plants, which have generated not only losses in the quality of agricultural products, but also in yield (28-68\% in large crops such as soybean

\section{RESUMO}

Ação bioherbicida de caldo fermentado de Phoma dimorpha em sementes e plantas de Senna obtusifolia

A planta daninha Senna obtusifolia causa severos danos em áreas de pastagens no Brasil, devido à sua elevada produção e disseminação de sementes. Objetivou-se avaliar a ação bioherbicida do caldo fermentado de Phoma dimorpha na pré-emergência e pós-emergência de $S$. obtusifolia. O delineamento experimental utilizado foi inteiramente casualizado, com dois tratamentos, um com e outro sem aplicação do caldo fermentado. Os efeitos bioherbicidas foram mensurados em bioensaios de pré-emergência (porcentagem de germinação), folhas destacadas (fitotoxicidade) e pós-emergência (fitotoxicidade, altura de planta e massa fresca de planta). A aplicação do caldo fermentado proporcionou ação bioherbicida em pré-emergência, inibindo em $100 \%$ a germinação das sementes. Em folhas destacadas, ocasionou necrose e morte das folhas no nono dia após a aplicação. Na pós-emergência, essa aplicação ocasionou sintomas moderados, como manchas nas folhas e redução no tamanho da planta daninha. Conclui-se que o caldo fermentado de $P$. dimorpha possui ação herbicida potencial e, por isso, representa uma alternativa no desenvolvimento de bioprodutos para o controle sustentável de plantas daninhas em pastagens.

PALAVRAS-CHAVE: Fedegoso, controle biológico, fitotoxidade, planta daninha.

and cotton), thus generating high economic losses (Pisula \& Meiners 2010, Suriyagoda et al. 2014, Bajwa et al. 2016).

The weed species most frequently found in pastures, orchards, annual and perennial plants in Brazil, and also in other countries, is Senna obtusifolia (L.) H. S. Irwin \& Barneby, popularly known in Brazil as "fedegoso", due to its characteristic bad odor, and also known as "bush-pasture", due to the

1. Received: Jan. 29, 2019. Accepted: May 28, 2019. Published: Nov. 01, 2019. DOI: 10.1590/1983-40632020v5056894.

2. Universidade Federal de Santa Maria, Centro de Ciências Rurais, Santa Maria, RS, Brasil.

E-mail/ORCID: jose.chavesneto@gmail.com/0000-0003-1799-4630.

3. Universidade Federal de Santa Maria, Departamento de Engenharia Química, Santa Maria, RS, Brasil.

E-mail/ORCID: marciomazutti@gmail.com/0000-0001-8217-5629.

4. Universidade Federal de Santa Maria, Laboratório de Engenharia de Processos Agroindustriais, Cachoeira do Sul, RS, Brasil.

E-mail/ORCID: giovani.zabot@gmail.com/0000-0001-7933-6161, marcus.tres@ufsm.br/0000-0001-5252-0735. 
damage it causes to pastures. Native of the American continent, it is classified as a bushy and woody plant, with approximately $70-160 \mathrm{~cm}$ of height (Lorenzi 2002).

Its potential as a weed is associated with its high seed production, as when the pods reach maturity, they spread their germinating seeds at the beginning of the rainy season. They are able to germinate and bloom over a wide temperature range $\left(18-36{ }^{\circ} \mathrm{C}\right)$; therefore, the seeds are the main way of propagation. In addition to these problematic characteristics, its competitive ability and toxicity to domestic animals cause problems in agricultural and pasture areas (Walker \& Oliver 2008, Peres et al. 2010).

Weed plant control is reached by cultural, mechanical, chemical or biological activities. In the last five decades, the use of chemical herbicides is the main measure of weed control systems (Jabran et al. 2015). Despite the widespread use and effectiveness of herbicides in the weed control, in recent years, weeds with multiple resistance to the action of certain chemical molecules have occurred (Jabran et al. 2015, Meuller-Steover et al. 2016).

Because of the difficult control of certain weed species, as well as the potential negative impacts of chemicals on the environment and human health, alternative methods are being developed, which are environmentally safe and biodegradable in nature, in order to reduce the use of synthetic herbicides (Bajwa et al. 2016). The biological control is an alternative for the substitution of agrochemicals, favoring the reduction of their use and minimizing the damages caused to the environment (Schwan-Estrada et al. 2000).

Biologically active secondary metabolites coming from fermented media of microorganisms are used in the agricultural environment for biological control. These offer several benefits, such as a greater specificity to the target plant, rapid degradation and reduction in the use of synthetic herbicides, being considered economically and environmentally viable (Baque et al. 2012, Cordeau et al. 2016). Among the sources of secondary metabolites, fungi are the most studied microorganism producers, since several species of endophytic fungi are considered a potential source of natural products, being an important source for the selection of agents of interest to the biological control (Baque et al. 2012).

The Phoma fungi are a source of secondary metabolites with high biological activity, as some species secrete secondary metabolites, which may be used for the manufacturing of products with bio-biocidal activity, as well as others, aimed at the biological control of phytopathogenic fungi and insects (Wijeratne et al. 2013). Several studies have shown that fungi of this genus produce a large variety of secondary metabolites with biological potential and they may be used for the formulation of bioproducts aimed at the agricultural environment (Hubbard et al. 2014, Brun et al. 2016, Todero et al. 2018b).

This study aimed to evaluate the bioherbicidal action of a fermented broth produced from Phoma dimorpha fungus in the pre-emergence and postemergence of $S$. obtusifolia.

\section{MATERIAL AND METHODS}

The bioassays were conducted at the Universidade Federal de Santa Maria (UFMS), in Santa Maria, Rio Grande do Sul state, Brazil, under laboratory (pre-emergence and detached leaf) and greenhouse (post-emergence) conditions, from May to July 2018. The microorganism used to obtain the fermented broth was a $P$. dimorpha (NRRL 43879) fungus strain originated from the collection of the Biotec Factory laboratory (UFMS).

The S. obtusifolia seeds used to perform the bioassays were collected in a pasture area located in Cuité de Mamanguape, Paraíba state, Brazil (06 $55^{\circ} 15.4$ 'S and 35 $\left.{ }^{\circ} 17^{\prime} 12.8^{\prime \prime} \mathrm{W}\right)$.

The fungus strain was maintained in Petri dishes containing BDA medium at $8{ }^{\circ} \mathrm{C}$, and subcultured every 15 days. For the fermentation process, Petri dishes containing the active growing fungus were kept in a bacteriological oven for 7 days, at $28{ }^{\circ} \mathrm{C}$, from which 2 mycelium disks of $6 \mathrm{~mm}$ were removed and transferred to Erlenmeyer flasks with $130 \mathrm{~mL}$ of a liquid medium containing potato extract $\left(200 \mathrm{~g} \mathrm{~L}^{-1}\right)$, dextrose $\left(20 \mathrm{~g} \mathrm{~L}^{-1}\right)$, peptone $\left(10 \mathrm{~g} \mathrm{~L}^{-1}\right)$, yeast extract $\left(7.5 \mathrm{~g} \mathrm{~L}^{-1}\right)$, ammonium sulfate $\left[\left(\mathrm{NH}_{4}\right)_{2} \mathrm{SO}_{4} ; 2 \mathrm{~g} \mathrm{~L}^{-1}\right]$, ferrous sulfate $\left(\mathrm{FeSO}_{4} \cdot 7 \mathrm{H}_{2} \mathrm{O}\right.$; $\left.1 \mathrm{~g} \mathrm{~L}^{-1}\right)$ and magnesium sulfate $\left(\mathrm{MgSO}_{4} ; 0.5 \mathrm{~g} \mathrm{~L}^{-1}\right.$ and $\mathrm{MnSO}_{4} \cdot \mathrm{H}_{2} \mathrm{O} ; 1 \mathrm{~g} \mathrm{~L}^{-1}$ ) (Zhang et al. 2012), previously sterilized by autoclaving at $121^{\circ} \mathrm{C}$, for $30 \mathrm{~min}$. The flasks were maintained at $28{ }^{\circ} \mathrm{C}$, under agitation of $120 \mathrm{rpm}$, for 10 days (Innova 44R, New Brunswick) (Klaic et al. 2017). After this period, the cells were separated from the fermented broth through a filter paper with $14 \mu \mathrm{m}$ pores in vacuum filtration with a 
Büchner funnel. The cell free fermented broth was stored in a freezer at $-20^{\circ} \mathrm{C}$, for 15 days. Then, three different bioassays were performed in order to verify the bioherbicidal action of the $P$. dimorpha fermented broth in pre-emergence, detached leaves and postemergence of S. obtusifolia.

In pre-emergence, the bioherbicidal action of the P. dimorpha fermented broth was evaluated through a germination test, with the seeds being initialy submitted to the overcoming mechanical scarification dormancy method (Bortolini et al. 2011).

The germination test was carried out in a completely randomized design, with two treatments (with and without application of the fermented broth) and eight replicates of 25 seeds. For this, sheets of filter paper $\left(\right.$ Germitest $\left.^{\circledR}\right)$ moistened with $4 \mathrm{~mL}$ of the different treatments were used. Then, the boxes were conditioned in a BOD germination chamber at $25^{\circ} \mathrm{C}$, with photoperiod of $12 / 12 \mathrm{~h}$ of light/darkness. The evaluations were carried out daily until reaching stabilization, counting the number of seeds that germinated, having as a criterion the protrusion of the minimum radicle of $2 \mathrm{~mm}$ in length (Brasil 2009).

Another bioassay in a completely randomized design, with the same two treatments (without and with application of the fermented broth), was used to assess the bioherbicidal action in the leaf. Four replications of one leaf each were used. With this aim, S. obtusifolia leaves with 15 days of growth were collected. These leaves were arranged in gerbox boxes previously disinfected with $70 \%$ ethanol and lined with two sheets of filter paper. Then, $3 \mathrm{~mL}$ of the fermented broth were applied and, for the control treatment, the same volume of distilled water was applied with the use of an automatic pipette on cotton wrapped in the leaf petiole. The gerbox boxes were conditioned in a BOD incubator chamber with temperature of $25^{\circ} \mathrm{C}$ and photoperiod of $12 / 12 \mathrm{~h}$ of light/darkness. The evaluations were carried out on the 3rd, 6th and 9th day after the application (Pedras \& Ahiahonu 2004, Todero et al. 2018b) for the analysis of the appearance of symptoms, according to the scale presented in Table 1 .

In post-emergence, the assay to evaluate the bioherbicidal action of the $P$. dimorpha fermented broth on the weed was carried out in a greenhouse. The S. obtusifolia culture was used for the subsequent application and evaluation of the treatments. The same two treatments were assigned completely randomized to ten replications each. Each experimental unit was composed of a polyethylene vessel with volume of

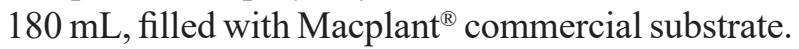
Initially, three seeds were sown in each vessel, and after the emergence of the seedlings, thinning was performed and only one plant was maintained per vessel, which was cultivated until the end of the experiment.

The application of the fermented broth was carried out at approximately 15 days after the emergence of the plants. For the application, a costal/ manual, $\mathrm{CO}_{2}$-pressurized sprayer and $300 \mathrm{~L} \mathrm{ha}^{-1}$ of syrup volume (Brun et al. 2016), was used. Phytotoxicity evaluations were performed at 15 days after the treatment (Todero et al. 2018b) and the leaf damage to plants was estimated visually, based on the scale presented in Table 1. Then, the plant height $(\mathrm{mm})$ and fresh plant mass $(\mathrm{g})$ were also measured. Based on the plant height data, the growth reduction (\%) of the treatment with application of the raw fungus fermented broth was calculated in relation to the control treatment (without fermented broth application).

The data were submitted to the normality and homogeneity errors tests, and then to the F-test of Anova, and the treatment means were compared by the Tukey test, adopting a significance level of $5 \%$. For this, the Sisvar software (Ferreira 2014) was used.

Table 1. Scale for evaluation of the phytotoxicity percentage in detached leaves and plants, developed based on the concepts applied to the toxicity assessments ${ }^{1}$.

\begin{tabular}{cl}
\hline Damage (\%) & \\
\hline $0-20$ & No injury or effect \\
$20-40$ & Slight injury and/or growth reduction with rapid recovery \\
$40-60$ & Moderate injury and/or growth reduction with slow or definitive recovery \\
$60-80$ & Severe injury and/or reduction of non-recoverable growth and/or reduction of the stand \\
$80-100$ & Complete destruction or just a few live plants \\
\hline${ }^{1}$ Source: SBCPD (1995). &
\end{tabular}




\section{RESULTS AND DISCUSSION}

A bioherbicidal action of the $P$. dimorpha fermented broth on the germination percentage of S. obtusifolia seeds was observed (Table 2). The application of the fermented broth presented a complete inhibition of the germination, with effectiveness in the order of $100 \%$ (Table 2 and Figure 1).

The seed germination inhibition observed in this study characterizes that the fungus fermented broth presents a bioherbicidal action and potential for the development of bioherbicides in the agricultural environment. Researches focused on weed biological control by application of secondary metabolites from fungi of the Phoma genus were also conducted by Cimmino et al. (2013), Hubbard et al. (2014), Evidente et al. (2015) and Todero et al. (2018b). These authors characterized phytotoxic effects in pre-emergence (germination reduction) and postemergence (spots, chlorosis, deformations and collapse of leaves, besides necrosis in plants) of several weed species.

Table 2. Mean germination percentage of Senna obtusifolia seeds resulting in normal seedlings after to the application of Phoma dimorpha fermented broth.

\begin{tabular}{lc}
\hline \multicolumn{1}{c}{ Treatment } & Germination (\%) \\
\hline Control (without fermented broth) & $99.00 \pm 1.51 \mathrm{a}$ \\
With fermented broth & $0.00 \pm 0.00 \mathrm{~b}$ \\
\hline MSD & 1.15 \\
\hline CV (\%) & 2.16 \\
\hline
\end{tabular}

${ }^{1}$ Means with distinct letters are statistically different by the Tukey test at $5 \%$ of probability. MSD: minimum significant difference; CV: coefficient of variation.
Similar results were reported by Brun et al. (2016), when evaluating the herbicide potential of raw fermented broth from Phoma sp. submerged in bioreactor on the seed germination of Cucumis sativus and Sorghum bicolor. They found that the application of this fermented broth caused a reduction in the germination, with percentages of $100 \%$ and $84 \%$ of inhibition, respectively. These authors suggest that a compound named Pyrrolo [1,2-a] pyrazine-1,4dione, hexahydro-3- (2-methylpropyl), found as a major compound in the chemical characterization of fermented extracts, has a herbicidal effect.

Todero et al. (2018a), when evaluating the effectiveness of the bioherbicidal activity of Phoma sp. fermented broth concentrated by membrane from submerged fermentation, found that a $30 \%$ concentrate in the pre-emergence of Bidens pilosa and Amaranthus retroflexus seeds reached an inhibition of $100 \%$ in all the dilutions used. These results are in agreement with those found in the present research, confirming the bioherbicidal action of the fermented broth produced by representatives of this fungus genus.

The percentage of phytotoxicity, as a function of the application of $P$. dimropha fermented broth, on leaves of S. obtusifolia is shown in Table 3. In the detached leaves of $S$. obtusifolia, there was yellowing ( $40 \%$ of phytotoxicity) since the first evaluation ( $72 \mathrm{~h}$ after the application), intensifying up to the last evaluation, performed at 9 days after the application of the raw fermented broth, when there were severe lesions with yellowing and marked necrosis, characterizing $90 \%$ of phytotoxicity (Table 3 and Figure 2).
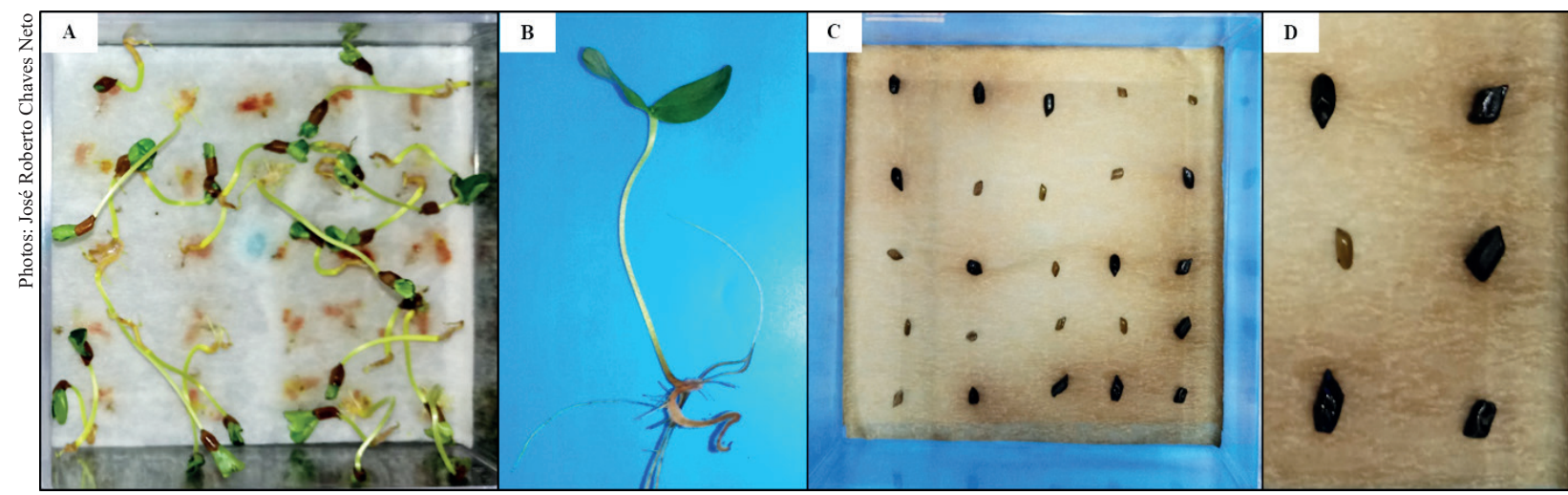

Figure 1. Phytotoxic test on seeds of Senna obtusifolia submitted to the application of Phoma dimorpha fermented broth. A) Control treatment (without fermented broth); B) seedling of the control treatment; C) treatment with application of the fermented broth; D) detail of the seed when the fermented broth was applied. 
Brun et al. (2016) and Todero et al. (2018a) reported similar phytotoxicity percentages, when evaluating the phytotoxic effect of Phoma sp. raw fermented broth on leaves of $C$. sativus. Yellowing and necrosis occurred on detached leaves of this species after $72 \mathrm{~h}$ of application $(30 \%$ of phytotoxicity), leading to the total leaf death in the last evaluation ( $80 \%$ of phytotoxicity).

Similar results were also described by Graupner et al. (2003), Vikrant et al. (2006) and Bailey et al. (2011a), when evaluating the application effectiveness of raw fermented broth of different Phoma species obtained by submerged fermentation on leaves of Cirsium arvense and Parthenium hysterophorus (white losna) plants. They observed a fast yellowing and chlorosis, evolving for leaf necrosis and death, as well as growth reduction.

The application of $P$. dimropha fermented broth resulted in leaf necrosis ( $30 \%$ of phytotoxicity) of $S$. obtusifolia plants at 15 days after the application (Table 4 and Figure 3). According to Mello et al. (2003), substances which are present in fermented

Table 3. Phytotoxicity on leaves of Senna obtusifolia at 3,6 and 9 days after the application (DAP) of Phoma dimorpha fermented broth.

\begin{tabular}{lcrr}
\hline \multirow{2}{*}{ Treatment } & \multicolumn{3}{c}{ Phytotoxicity (\%) } \\
\cline { 2 - 4 } & \multicolumn{1}{c}{ 3 DAP } & 6 DAP & 9 DAP \\
\hline Control (without fermented broth) & $0.00 \pm 0.00 \mathrm{~b}$ & $0.00 \pm 0.00 \mathrm{~b}$ & $0.00 \pm 0.00 \mathrm{~b}$ \\
With fermented broth & $40.00 \pm 8.16 \mathrm{a}$ & $70.00 \pm 8.16 \mathrm{a}$ & $90.00 \pm 8.16 \mathrm{a}$ \\
\hline MSD & 9.99 & 9.99 & 9.99 \\
\hline CV (\%) & 28.87 & 16.50 & 12.83 \\
\hline
\end{tabular}

Table 4. Means ${ }^{1}$ of plant phytotoxicity, plant height, growth reduction and fresh mass of Senna obtusifolia plants at 15 days after the application of Phoma dimorpha fermented broth.

\begin{tabular}{lcccc}
\hline \multicolumn{1}{c}{ Treatment } & Phytotoxicity (\%) & Plant height $(\mathrm{cm})$ & Growth reduction (\%) & Fresh mass (g) \\
\hline Control (without broth) & $0.00 \pm 0.00 \mathrm{~b}$ & $8.43 \pm 0.76 \mathrm{a}$ & $0.00 \pm 0.00 \mathrm{~b}$ & $1.97 \pm 0.45 \mathrm{a}$ \\
With fermented broth & $30.00 \pm 4.08 \mathrm{a}$ & $6.93 \pm 0.70 \mathrm{~b}$ & $20.80 \pm 2.07 \mathrm{a}$ & $1.20 \pm 0.14 \mathrm{~b}$ \\
\hline MSD & 2.71 & 0.69 & 8.48 & 0.31 \\
\hline CV $(\%)$ & 19.25 & 10.06 & 26.68 & 21.15 \\
\hline
\end{tabular}

${ }^{1}$ Means with distinct letters are statistically different by the Tukey test at $5 \%$ of probability. MSD: minimum significant difference; CV: coefficient of variation.

0 DAP

3 DAP

6 DAP

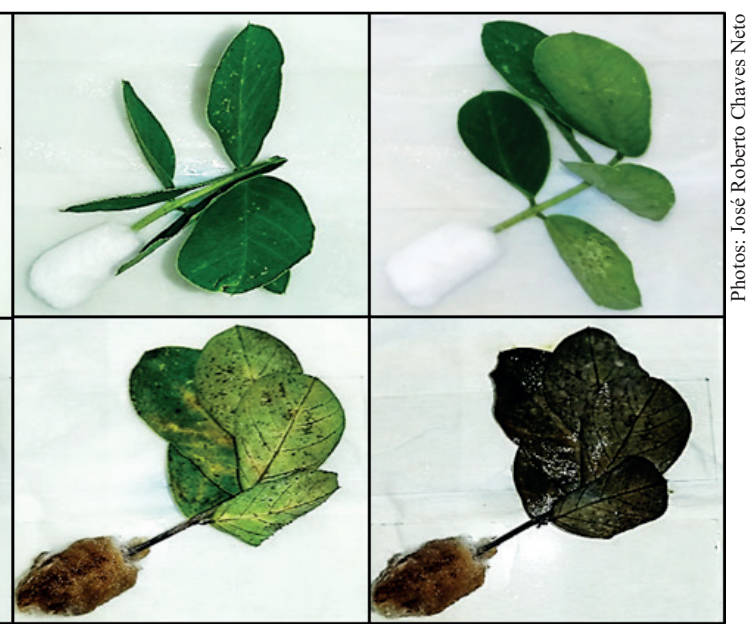

Figure 2. Phytotoxic effects on leaves of Senna obtusifolia after 3, 6 and 9 days after the application (DAP) of Phoma dimorpha fermented broth (T1: control treatment without the fermented broth; $\mathrm{T} 2$ : treatment with the fermented broth). 


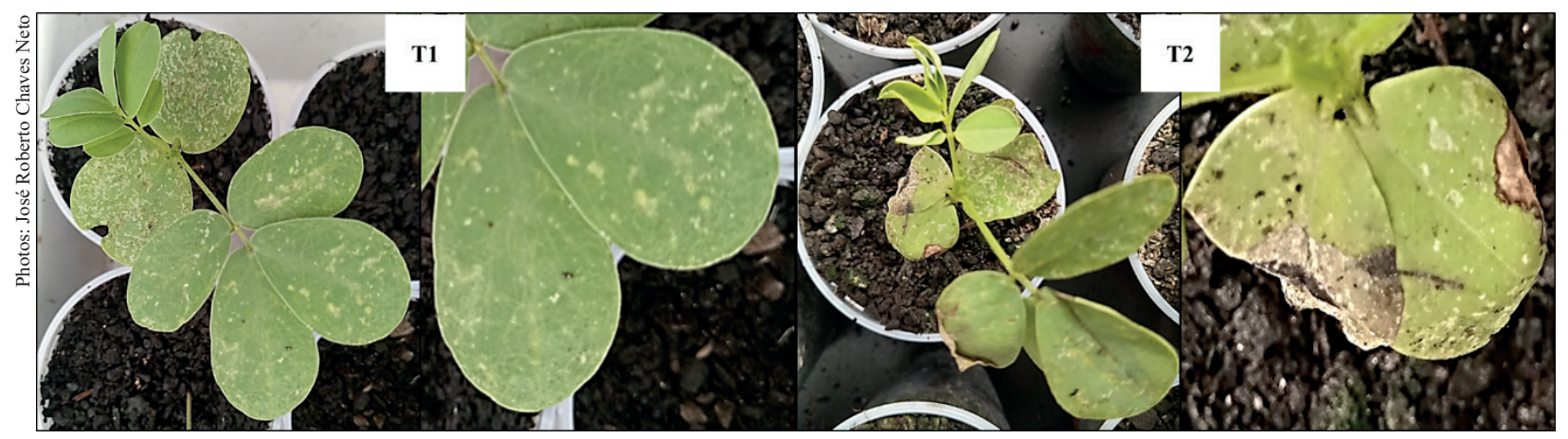

Figure 3. Phytotoxic effect on Senna obtusifolia plants at 15 days after the application of Phoma dimorpha fermented broth (T1: control treatment without the fermented broth; T2: treatment with the fermented broth).

fungi may cause symptoms such as chlorosis, wilt, waterlogging and alteration in plant growth.

According to Bailey et al. (2011b), the macrocidin $\mathrm{A}$ and $\mathrm{Z}$ compounds produced by the Phoma macrostoma fungus have as their mode of action the inhibition of the carotenoid biosynthesis, inducing chlorosis, bleaching and eventual necrosis in susceptible plants. These authors observed that compounds applications produce symptoms of photodegradation in broadleaf weeds such as Cirsium arvense, Taraxacum officinale and Stellaria media.

Similar results were found by Cimmino et al. (2013), who evaluated the isolated potential of the chenopodoline metabolite produced by the P. chenopodicola fungus in leaves of Cirsium arvense and Setaria viridis. They reported symptoms such as necrosis, wilt and foliar tissue degradation. Todero et al. (2018a) reported that the application of fermented Phoma sp. in post-emergence of C. sativus plants caused yellowing at 7 days after the application, evolving up to the occurrence of wilting and necrotic lesions. In addition, these authors observed alterations in plant growth.

A significant difference $(\mathrm{p}<0.05)$ was observed for plant height with the application of the $P$. dimorpha fermented broth on $S$. obtusifolia plants, resulting in a lower height (Table 4). Similar results were observed by Klaic et al. (2017), who found a reduction of $30 \%$ in the plant height of the bioindicator C. sativus, when submitted to the same fermented broth.

The influence of the $P$. dimorpha fermented broth on the plant height of $S$. obtusifolia was confirmed by the reduction in the growth percentage (Table 4). Hence, it was possible to conclude that the application of this fermented broth causes a significant growth reduction in plants of $S$. obtusifolia. Similar results were found by Todero et al. (2018b), when evaluating formulations with secondary metabolites from submerged Phoma sp. with herbicidal action against the weed species Bidens pilosa, Amaranthus retroflexus and Conyza canadensis. These authors observed a reduction of $31 \%$ in plant height. According to Gronwald et al. (2002), the weed growth reduction is a factor to determine the bioherbicide potential.

The fresh mass of $S$. obtusifolia plants was also reduced with the application of the $P$. dimorpha fermented broth (Table 4). This reduction, as a function of the fermented broth, was also observed by Brun et al. (2016) on C. sativus plants at 7 days after the application of Phoma sp. Similarly, Klaic et al. (2017), after optimizing the solid state fermentation process for the production of the bioherbicide through Phoma sp. secondary metabolites, also observed its phytotoxicity on C. sativus plants, with a reduction of $20 \%$ in the fresh mass, in comparison to the control treatment.

\section{CONCLUSION}

The application of Phoma dimorpha fermented broth provides a pre-emergence bioherbicidal action on Senna obtusifolia. This treatment inhibited the seed germination in $100 \%$. On detached leaves, it caused leaf necrosis and death at the ninth day after the application. In the post-emergence, the application caused leaf spots, as well as reduced the size and fresh mass of this weed. Thus, the P. dimorpha fermented broth has proved to be an alternative for the development of weed management 
bioproducts, with a view of reducing the use of the synthetic herbicides and preventing pollution in pasture ecosystems.

\section{REFERENCES}

BAILEY, K. L.; PITT, W. M.; FALK, S.; DERBY, J. The effects of Phoma macrostoma on nontarget plant and target weed species. Biological Control, v. 58, n. 1, p. 379-386, $2011 b$.

BAILEY, K. L.; PITT, W. M.; LEGGETT, F.; SHEEDY, C.; DERBY, J. Determining the infection process of Phoma macrostoma that leads to bioherbicidal activity on broadleaved weeds. Biological Control, v. 59, n. 2, p. 268-276, 2011a.

BAJWA, A. A.; SADIA, S.; ALI, H. H.; JABRAN, K.; PEERZADA, A. M.; CHAUHAN, B. S. Biology and management of two important Conyza weeds: a global review. Environmental Science and Pollution Research, v. 23, n. 24, p. 24694-24710, 2016.

BAQUE, M. A.; MOH, S. H.; LEE, E. J.; ZHONG, J. J.; PAEK, K. Y. Production of biomass and useful compounds from adventitious roots of high-value added medicinal plants using bioreactor. Biotechnology Advances, v. 30, n. 6, p. 1255-1267, 2012.

BORTOLINI, M. F.; KOEHLER, H. S.; ZUFFELLATORIBAS, K. C.; MALAVASI, M. M.; FORTES, A. M. T. Superação de dormência em sementes de Gleditschia amorphoides Taub. Ciência Rural, v. 41, n. 5, p. 823-827, 2011.

BRASIL. Ministério da Agricultura, Pecuária e Abastecimento. Regras para análise de sementes. Brasília, DF: MAPA/ACS, 2009.

BRUN, T.; RABUSKE, J. E.; TODERO, I.; ALMEIDA, T. C.; JUNIOR, J. J. D.; ARIOTTI, G.; CONFORTIN, T. C.; ARNEMANN, J. A.; KUHN, R. C.; GUEDES, J. V. C.; MAZUTTI, M. A. Production of bioherbicide by Phoma sp. in a stirred-tank bioreactor. 3 Biotech, v. 6, n. 2, p. 230-239, 2016.

CIMMINO, A.; ANDOLFI, A.; ZONNO, M. C.; AVOLIO, F.; BERESTETSKIY, A.; VURRO, M.; EVIDENTE, A. Chenopodolin: a phytotoxic unrearranged ent-pimaradiene diterpene produced by Phoma chenopodicola, a fungal pathogen for chenopodium album biocontrol. Journal of Natural Products, v. 76, n. 7, p. 1291-1297, 2013.

CORDEAU, S.; TRIOLET, M.; WAYMAN, S.; STEINBERG, C.; GUILLEMINA, J-P. Bioherbicides: dead in the water?: a review of the existing products for integrated weed management. Crop Protection, v. 87, n. 1, p. 44-49, 2016.
EVIDENTE, M.; CIMMINO, A.; ZONNO, M. C.; MASI, M.; BERESTETSKYI, A.; SANTORO, E.; SUPERCHI, E.; VURRO, M.; EVIDENTE, A. Phytotoxins produced by Phoma chenopodiicola, a fungal pathogen of Chenopodium album. Phytochemistry, v. 117, n. 1, p. 482-488, 2015.

FERREIRA, D. F. Sisvar: a guide for its bootstrap procedures in multiple comparisons. Ciência \& Agrotecnologia, v. 38, n. 2, p. 109-112, 2014.

GRAUPNER, P. R.; CARR, A.; CLANCY, E.; GILBERT, J.; BAILEY, K. L.; DERBY, J. A.; GERWICK, B. C. The macrocidins: novel cyclic tetramic acids with herbicidal activity produced by Phoma macrostoma. Journal of Natural Products, v. 66, n. 12, p. 1558-1561, 2003.

GRONWALD, J. W.; PLAISANCE, K. L.; IDE, D. A.; WYSE, D. L. Assessment of Pseudomonas syringae pv. tagetis as a biocontrol agent for Canada thistle. Weed Science, v. 50, n. 3, p. 397-404, 2002.

HUBBARD, M.; HYNES, R. K.; ERLANDSON, M.; BAILEY, K. L. The biochemistry behind biopesticide efficacy. Sustainable Chemical Processes, v. 2, n. 18, p. 1-8, 2014.

JABRAN, K.; MAHAJAN, G.; SARDANA, V.; CHAUHAN, B. S. Allelopathy for weed control in agricultural systems. Crop Protection, v. 72, n. 1, p. $57-$ 65, 2015.

KLAIC, R.; SALLET, D.; FOLETTO, E. L.; JACQUES, R. J. S.; GUEDES, J. V. C.; KUHN, R. C.; MAZUTTI, M. A. Optimization of solid-state fermentation for bioherbicide production by Phoma sp. Brazilian Journal of Chemical Engineering, v. 34, n. 2, p. 377-384, 2017.

LORENZI, H. Plantas daninhas do Brasil: terrestres e aquáticas, parasitas e tóxicas. 4. ed. Nova Odessa: Instituto Plantarum de Estudos da Flora, 2002.

MELLO, S. C. M.; TEIXEIRA, E. A.; BORGES NETO, C. R. Fungos e seus metabólitos no controle da tiririca. Brasília, DF: Embrapa Recursos Genéticos e Biotecnologia, 2003. (Documentos, 104).

MEULLER-STEOVER, D.; NYBROE, O.; BARAIBAR, B.; LODDO, D.; EIZENBERG, H.; FRENCH, K.; SØNDERSKOV, M.; NEVE, P.; PELTZER, D. A.; MACZEY, N.; CHRISTENSEN, S. Contribution of the seed microbiome to weed management. Weed Research, v. 56, n. 5, p. 335-339, 2016.

PEDRAS, M. S.; AHIAHONU, P. W. Phytotoxin production and phytoalexin elicitation by the phytopathogenic fungus Sclerotinia sclerotiorum. Journal of Chemical Ecology, v. 30, n. 11, p. 2163-2179, 2004.

PERES, M. T. L. P.; CÂNDIDO, A. C. S.; BONILLA, M. B.; FACCENDA, O.; HESS, S. C. Phytotoxic potential of Senna occidentalis and Senna obtusifolia. Acta 
Scientiarum. Biological Sciences, v. 32, n. 3, p. 305-309, 2010.

PISULA, N. L.; MEINERS, S. J. Relative allelopathic potential of invasive plant species in a young disturbed woodland. Journal of the Torrey Botanical Society, v. 137, n. 1, p. 81-87, 2010.

SCHWAN-ESTRADA, K. R. F.; STANGARLIN, J. R.; CRUZ, E. E. S. Uso de extratos vegetais no controle de fungos fitopatogênicos. Floresta, v. 30, n. 1-2, p. $129-$ 137, 2000.

SOCIEDADE BRASILEIRA DA CIÊNCIA DAS PLANTAS DANINHAS (SBCPD). Procedimentos para instalação, avaliação e análise de experimentos com herbicidas. Londrina: SBCPD, 1995.

SURIYAGODA, L.; COSTA, W. A. J. M.; LAMBERS, H. Growth and phosphorus nutrition of rice when inorganic fertiliser application is partly replaced by straw under varying moisture availability in sandy and clay soils. Plant Soil, v. 384, n. 1-2, p. 53-68, 2014.

TODERO, I.; CONFORTIN, T. C.; LUFT, L.; BRUN, T.; UGALDE, G. A.; ALMEITA, T. C.; ARNEMANN, J. A.; ZABOT, G. L.; MAZUTTI, M. A. Formulation of a bioherbicide with metabolites from Phoma sp. Scientia Horticulturae, v. 241, n. 1, p. 285-292, 2018 b.
TODERO, I.; CONFORTIN, T. C.; SOARES, J. F.; BRUN, T.; LUFT, L.; RABUSKE, J. E.; KUHN, R. C.; TRES, M. V.; ZABOT, G. L.; MAZUTTI, M. A. Concentration of metabolites from Phoma sp. using microfiltration membrane for increasing bioherbicidal activity. Environmental Technology, v. 22, n. 1, p. 1-9, 2018a.

VIKRANT, P.; VERMA, K. K.; RAJAK, R. C.; PANDEY, A. K. Characterization of a phytotoxin from Phoma herbarum for management of Parthenium hysterophorus $\mathrm{L}$. Journal of Phytopathology, v. 154, n. 1, p. 461-468, 2006.

WALKER, E. R.; OLIVER, L. R. Translocation and absorption of glyphosate in flowering sicklepod (Senna obtusifolia). Weed Science, v. 56, n. 3, p. 338-343, 2008.

WIJERATNE, E. M. K.; HE, H.; FRANZBLAU, S. G.; HOFFMAN, A. M.; GUNATILAKA, A. A. L. Phomapyrrolidones A-C, antitubercular alkaloids from the endophytic fungus Phoma sp. NRRL 46751. Journal of Natural Products, v. 76, n. 10, p. 1860-1865, 2013.

ZHANG, L.; WANG, S-Q.; LI, X-J.; ZHANG, A-L.; ZHANG, Q.; GAO, J-M. New insight into the stereochemistry of botryosphaeridione from a Phoma endophyte. Journal of Molecular Structure, v. 1016, n. 1, p. 72-75, 2012. 